\title{
7 \\ Drought and Water in the Murray-Darling basin: From Disaster Policy to Adaptation
}

LINDA C. BOTTERILL AND STEPHEN DOVERS

In 1989, Australian government policy ceased to consider drought as a natural disaster but rather viewed it as a problem of risk management in a highly variable climate. This fundamental shift was a long time in the making and has not been without implementation difficulties; however, the experience contains lessons for climate change adaptation for communities and policymakers. Adaptation and disasters are about coping with greater frequency and/or intensity of climate-related events storms, flooding, heat waves, cyclones and so on. If these events become more norm than exception, then a similar policy shift from disaster preparation and relief to risk management can be expected. The shift is consistent with evolution of emergency and disaster theory and practice, from natural disasters and 'acts of God' to risk management to deal with the intersection of environmental variation and human vulnerability across hazard types (Handmer and Dovers, 2013). Like other insights from cognate policy and research domains, this shift has yet to be comprehended in much adaptation literature (Dovers and Hezri, 2010).

We summarise the history of drought policy in Australia and the political, cultural and other issues embedded in the process of policy change. We then comment on the intersection of drought policy with the closely related issue of water allocation in the Murray-Darling Basin under conditions of scarcity and climate variability.

\subsection{Drought Policy Pre-1989}

Until 1989, Austtalian governments regarded droughts as natural disasters and responded in line with their treatment of cyclones, wildfires, earthquakes and floods. Constitutionally, disaster response is a state (provincial) government responsibility. However, the national government increasingly became involved in delivery of disaster relief after its first intervention to assist the State of Tasmania following major wildfires in 1939. Over the next three decades, a cost-sharing arrangement emerged between the 
Commonwealth and states, augmented on a number of occasions by special Commonwealth legislation for a number of disasters, including the drought of 1965/66, and was formalised in 1971 as the natural disaster relief arrangements (NDRA). The NDRA sets out the respective responsibilities of the Commonwealth and states in the event of a disaster and provides a formula for cost sharing. Responsibility for declaring a natural disaster remains with the states, and the Commonwealth accepts these declarations as the basis for triggering the activation of the NDRA

In 1989, the Commonwealth Government decided that drought was no longer to be covered by the NDRA for three reasons. First, throughout 1989, the media carried reports of apparent misuse of drought assistance for party political purposes by the Queensiand State Government. Second and related to this were financial considerations. Drought relief was dominating NDRA expenditure, particularly in Queensland, where it accounted for all Commonwealth expenditure on disaster relief in 1984 to 1984/85, 1986/87, and 1987/88 (Courtice, 1989: 1379). Third, scientific advances in understanding of the Australian climate meant it was increasingly untenable to sustaln the position that drought was a disaster or 'act of God'. There was growing acceptance that drought was a normal consequence of Australia's highly variable clinate.

\subsection{The Policy Transition}

The removal of drought from the NDRA was a watershed decision. In May 1990 , the Minister for Primary Industries and Energy established a Drought Policy Review Task Force to identify policy options that encouraged primary producers and other segments of rural Australia to adopt self-reliant approaches to the management of drought; consider the integration of drought policy with other policies; and advise on priorities for Commonwealth Government action in minimising the effects of drought in the rural sector (Drought Policy Review Task Force, 1990). The Task Force concluded that drought was a normal part of the Australian chimate and a risk to be managed by agricultural producers along with the other risks facing farms. It concluded that 'Managing for drought is about managing for the risks involved in carrying out an agricultural business, given the variability of climate. Drought represents the continuing risk that seasonal conditions will not be adequate to sustain agricultural activity' (Drought Policy Review Task Force, 1990: 3).

The Task Force called for development of a national drought policy as a 'matter of urgency' (Drought Policy Review Task Force, 1990: 21). Over the next two years, Commonwealth and state governments negotiated the contents of such a policy. The new National Drought Policy was announced in July 1992, based on principles of self-reliance, risk management and acceptance that drought is a natural feature of the Australian climate (ACANZ, 1992). The objectives of the policy were to:
- encourage primar. approaches to mar.

- facilitate the mair resource base duri

- facilitate the early sustainable levels

The policy was I been reviewed con 1993. The key fea form of support $f$. Scheme, which pr subsidies'). These agriculture and ws itability and susta the level, of subsid income-smoothing management bond to be used during Management Dep was the Farm Ho have a long-term provided a level o it did not undermi future. The Farm component as inc

In 1994, follos duced with the a payment availabls the health of their had been tightly 1992: 14). Over 1 cumstances Payn dominate the dro ment continued t policy became in the policy impler. circumstances' d nying material th been subject to to provide an or 
r special Comyht of $1965 / 66$, s (NDRA). The in and states in sponsibility for awealth accepts RA. las no Jonger to ie media carried purposes by the ncial considera$y$ in Queensland, relief in 1984 to entific advances gly untenable to ere was growing 3 highly variable

2n. In May 1990 , sht Policy Review jducers and other e management of licies; and advise ing the effects of , 1990). The Task climate and a risk isks facing farms. the risks involved i climate. Drought adequate to sustain ).

policy as a 'matter the next two years, : such a policy. The ed on principles of atural feature of the were to:
- encourage primary producers and other sections of rural Australia to adopt self-reliant approaches to managing for climatic variability;

- facilitate the maintenance and protection of Australia's agricultural and environmental resource base during periods of increasing climate stress; and

- facilitate the early recovery of agricultural and ural industries, consistent with long-term sustainable levels (ACANZ, 1992).

The policy was built on a number of Commonwealth programs for farmers that had been reviewed concurrently. The package of measures came into effect on 1 January 1993. The key features of the drought policy were as follows. First, the main direct form of support for farm businesses was delivered through the Rural Adjustment Scheme, which provided subsidies on interest paid on commercial finance ("interest subsidies'). These were available to farmers with a long-term productive future in agriculture and were offered to support measures by farmers to improve farm profitability and sustainability. During severe droughts - "exceptional circumstances' the level of subsidy was increased. Second, the Commonwealth offered tax-effective income-smoothing mechanisms in the form of income equalisation deposits and farm management bonds, which allowed farmers to put aside money in high-income years to be used during drought. These two schemes were later combinted to form the Farm Managernent Deposits Scheme, which remains in place. The third major component was the Fiarn1 Household Support Scheme. This was aimed at farmers who did not have a long-term sustainable future in agriculture and was linked to exit grants. It provided a level of welfare support but was structured in such a way as to ensure that it did not undermine the policy objective of only supporting farms with a sustainable future. The Fann Household Support Scheme was time limited and contained a loan component as incentive for non-profitable farmers to leave the industry.

In 1994, following political pressure during drought, a major change was introduced with the announcement of the drought relief payment. This was a welfare payment available to all farmers in an exceptional circumstances area, irrespective of the health of their businesses. This was a major policy shift, as previous drought relief had been tightly targeted at those that were 'profitable in the long term' (ACANZ, 1992: 14). Over the next two decades, this payment, renamed the Exceptional Circumstances Payment, became increasingly generous (Botterill, 2006) and began to dominate the drought relief budget. The rhetoric of self-reliance and risk management continued to be employed by both sides of politics, but implementation of the policy became increasingly inconsistent with these objectives. A major problem with the policy implementation relates to the distinction between normal and 'exceptional circumstances' drought. There was no definition in the legislation or in accompanying material that gave effect to the policy. As a consequence, the definition has been subject to ongoing debate. This has undermined the intention of the policy to provide an ongoing, predictable policy response to drought, unlike the ad hoc 
approaches of the pre-1989 policy. For a more detailed account of the development and evolution of Australia's National Drought Policy, see Botterill (2003; 2005). A recent report by Australia's Productivity Commission has recommended that the exceptional circumstances declaration process and the associated government support packages be terminated (Productivity Commission, 2009). An Intergovernmental Agreement on Drought Policy Reform was signed in May 2013, the language of which is strikingly similar to that of the 1992 National Drought Policy. It sets out to 'replace the exceptional circumstances arrangements' with 'a new package of national drought programs' however the focus and structure of these new programs appears little different from their predecessors.

It is worth noting the narrow focus of Australian drought policy on agricultural production. The policy was developed within the agriculture department, then the Department of Primary Industries and Energy, and from 1996 until 2007 the Cabinet Minister responsible for this portfolio was from the farmer-based National Party. This famer-centric approach meant the impact of drought on town water supplies and indeed on irrigated agricultural production was given scant attention. Some measures to assist farm-dependent small businesses in rural areas were added some years into the program, but predominantly drought policy has been agricultural industry policy. In spite of this narrow focus, the policy can be seen as a pilot study of attitudinål change and adaptation as policy discourse shifted from disaster response to risk management. Although there has been some backsliding from the policy's original objectives, there has been broad acceptance across the political spectrum that drought is not a disaster. In developing its response to a series of inquiries into drought policy in 2008 (Drought Policy Review Expert Social Panel, 2008; Hennessy et al., 2008; Productivity Commission, 2009), the Australian Govemment in cooperation with the Western Australian State Government ran a drought 'pilot'. A review panel of the progress of the pilot was largely favorable (Drought Pilot Review Panel, 2011).

This short history demonstrates the often long and variable process of policy reform and two key issues of relevance to climate adaptation and extreme events. First, it is likely that, should extremes other than drought - for example, storms, coastal surges, heatwaves - become more frequent, a similar shift from exception to expected may occur, with demands for similar policy shifts. Second, this case evidences the fact that, very often, a considered policy shift can be reconsidered, at least in part. This appears to be the case with, for example, the treatment of the welfare component of the Western Australian drought policy pilot. Policy reform is a long-term task. However, in light of the clear need for adaptation policy to be cross-sectoral and thus for horizontal policy integration or 'mainstreaming' (Ahmad, 2009; Dovers and Fezri, 2010), the question arises of whether Australian policy addressed or was coordinated with connected impacts and policy sectors. In the space constraints here, we focus on one: Water allocation in the Murray-Darling Basin (MDB).

The MDB is Au depends on irrigat (Snith, 1998) anc jurisdictions allow of environmental led to a sequence with a history of a basin-wide interg as was the imposi two measures nor was the inclusion 1990s under the ul Governments (Cr proper pricing of part of a strong $p$ than previous atte

Elements of th: ented 2002 to 201 monitoring and $e$ have enabled anc most comprehens see www.nwe.go sustainable devel is the core aim. $f$ been on the MDE

Key elements :

- A comprehensivi to statutory wate of water markets

- Two independent Darling Basin A

- An unprecedente advances in the $c$

- A basin plan, to

- Significant fundi

Similar to drou principle that wat change, whereas 
development 2003; 2005). inded that the ernment supgovernmental : language of $\therefore$ It sets out to ige of national ᄁrams appears

on agricultural nent, then the 07 the Cabinet nal Party. This ir supplies and 1. Some measled some years Iltural industry pilot study of saster response sm the policy's itical spectrum of inquiries into 2008; Hennessy ment in cooperpilot'. A review it Review Panel,

of policy reform vents. First, it is 3 , coastal surges, to expected may iidences the fact zast in part. This Ifare component I long-term task sectoral and thus Jovers and Hezri, "was coordinated here, we focus on

\subsection{Drought and Water Allocation}

The MDB is Australia's largest river basin and agricultural production area and depends on irrigation from regulated rivers. Post-World War II irrigation development (Smith, 1998) and weak and inconsistent policy settings across four state (provincial) jurisdictions allowed a situation of serious over-allocation to emerge, largely at the cost of environmental condition (Connell, 2007). Periodic water shortages from droughts led to a sequence of crises and policy responses in the early $1980 \mathrm{~s}, 1990 \mathrm{~s}$ and $2000 \mathrm{~s}$, with a history of a lessening of reform when climatic conditions ease. The creation of basin-wide intergovernmental arrangements in the 1980s was a pivotal achievement, as was the imposition of a cap on overall water use a decade later, deficiencies of these two measures notwithstanding. More fundamental from a public policy perspective was the inclusion of the water sector in profound micro-economic reforms in the mid1990 s under the umbrella of National Competition Policy via the Council of Australian Governments (CoAG). The 'CoAG water reforms' promoted greater self-reliance, proper pricing of water delivery, environmental water flows and water markets. As part of a strong process of economy-wide reforms, they were of longer-term impact than previous attempts.

Elements of this policy history were brought together in response to the unprecedented 2002 to 2008 drought. A series of intersecting intergovernmental agreements, monitoring and evaluation functions, information systems and institutional reforms have enabled and furthered the 2004 National Water Initiative (NWI), the world's most comprehensive water reform package (Hussey and Dovers, 2007; NWC, 2009; see wwW.nWc.govau). Water allocation under conditions of variability to achieve sustainable development balance across environmental, social and economic values is the core aim. Although national in a genuine sense, the overwhelming focus has been on the MDB as Australia's most troubled water system.

Key elements are:

- A comprehensive intergovernmental agreement and new national water laws, giving effect to statutory water planning, definition of sustainable limits to extraction and establishment of water markets as a key policy instrument

- Two independent statutory authorities, the National Water Commission (NWC) and MurrayDarling Basin Authority (MDBA)

- An unprecedented biennial assessment process (NWC, 2007; 2009) supported by significant advances in the quantity and quality of water and associated data

- A basin plar, to reform water allocations

- Signiflcant funding aimed to encourage and enable reforms

Similar to drought policy, risk-sharing formulae have been established, based on the principle that water users should bear the risk of climate variability and future climate change, whereas governments are responsible for the impacts of policy change. 
Redressing over-allocation and environmental degradation through limits to extraction, water planning, technological improvernent, water markets and environmental flow provision must involve a reduction in overall use and re-allocation of water from consumptive to environmental uses. However, in 2010, the 'guidelines' for the Draft Basin Plan, incorporating significant allocation reductions in the order of those widely foreshadowed within the policy community, have been met with severe criticism that social and economic values had been overlooked in favour of environmental sustainability. The process of attempting to 'sell' the guidelines to affected agricultural producers in the Basin attracted a harsh response and a 'somewhat remarkable media frenzy' (Crase, 2011: 84). The public conversation failed to define over-allocation as a collective problem, and the matter was forced to be reviewed. Public meetings held throughout the Basin have served to dichotomise communities and the environment rather than link their futures. At the time of writing, this situation will (1) clearly take some time to resolve and may delay the MDB Plan, and (2) may even stall or reverse the policy directions built up over two decades. This situation might have been avoided had the policy process incorporated more recognition of the values of affected producers and communities.

Strangely, water reform does not deal directly with drought, even though climate variability is at the core, and drought policy does not deal with water allocation. The nectssity of cross-sectoral (horizontal) policy integration has not been addressed. Similarly, industry policy over the 1980 and 1990 s has been often unconnected to drought and water policy, as with structural adjustment measures that saw the dairy industry shift from (high-value) rain-fed coastal land to itrigated inland areas with resulting increased demands on $\mathrm{MDB}$ water. The imperative to horizontally coordinate policy is as intense as it is difficult in Australia as elsewhere (Ross and Dovers, 2008).

The MDB has been the major focus of water and therefore drought policy debates over recent decades, but the pattern is repeated elsewhere. The distinctly separate urban water policy domain has exhibited a similar history of reliance on 'predict-andprovide', supply-oriented approaches, punctuated by crisis management in drought and a lack of ongoing reform. In the wake of the 2002 to 2008 drought and the NWI, urban water has received much more attention, but also crisis-driven approaches dominated by the commissioning of large-scale desalination plants to augment supply, as well as some more adaptive management of behaviour and demand (Troy, 2008).

\subsection{Lessons for Adaptation}

In water and drought policy, as with disaster policy (Handmer and Dovers, 2013), a pattern of crisis-response-forgetting is common, as are the very real social and political pressures that inevitably (and properly) influence policy reform. If climate change results in more frequent and/or intense variability and thus drought, the difficulties for 
mits to extracenvironmental I of water from 's for the Draft of those widely e criticism that ronmental susted agricultural narkable media er-allocation as $\approx$ meetings held he environment will (1) clearly ay even stall or ion might have of the values of

I though climate water allocation. : been addressed. unconnected to lat saw the dairy nland areas with intally coordinate .oss and Dovers,

ht policy debates istinctly separate 2 on 'predict-andement in drought drought and the Iriven approaches o augment supply, and (Troy, 2008).

1 Dovers, 2013), a social and political If climate change , the difficulties for policymakers will intensify. So too will the likelihood of post-event regress. Drought in a variable climate is not a 'disaster' in the traditional sense, however disastrous the impacts on individuals, sectors and communities might be; the same is true for water shortages in a variable climate. Designing, implementing and especially maintaining policy regimes over the longer term is difficult.

Lessons from drought and water policy reform (and lack thereof) in the MurrayDarling Basin are relevant to other sectors. With increased variability, pressures to accept climate extremes and related disturbances to societies and environments, as expectable if not predictable, and to cater for these through robust, transparent policy settings will increase across events types. The alternative is ad hoc response to escalating impacts. The importance of understanding the policy history and path dependencies of specific sectors is important, as is the recognition of the complexities of public administrative, policy process, statutory and institutional mechanisms required. Ensuring cross-sectoral (horizontal) policy coordination, such as between drought and water, is a major challenge, as is cross-jurisdictional (vertical) coordination in a federal system such as Australia. The economic and political realities of resource- or place-dependent communities are highlighted, as is the importance of clear definitions of thresholds such as 'exceptional circumstances'. The use of triggers is a contentious policy issue, and there are arguments both for and against declarations as the basis for government intervention. The lessons from the National Drought Mitigation Center in the US suggest that the key to the implementation of woikable, politically acceptable definitions is the development of triggers based on comprehensive, composite indicators that are developed in consultation with stakeholder groups.

However, there is a basis for believing this can be done, the difficulties noted here notwithstanding. Such policy development is consistent with policy trends in emergency management toward greater risk sharing and preparedness, with neoliberalinspired public policy preferences toward self-reliance and risk management and with imperatives of policy integration. Much climate change adaptation can be addressed by "normalising" adaptation, or increasing existing imperatives and capacities for reform across many sectors by incorporating the prospect of increased climate variability. The last challenge - cross-sectoral policy coordination - will be a particularly hard one. The future will be more of the same, but likely much more.

\section{References}

ACANZ - Agticulture Council of Australia and New Zealand (1992). Record and Resolutions: 138th Meeting, Mackay 24 July 1992. Canberra: Commonwealth of Australia.

Ahmad, I. H. (2009). Climate Policy Integration: Towards Operationalization, Working Paper 73. Washington, DC: United Nations Department of Social and Economic Affairs,

Botterill, L. C. (2003), Uncertain climate: the recent history of drought policy in Australia. Australian Journal of Politics and History, 49, 61-74.

Botterill, L. C. (2005). Late twentieth century approaches to living with uncertainty: the National Drought Policy. In From Disaster Response to Risk Management: Australia's 
National Drought Policy, ed. L. C. Botterill and D. A. Wilhite, Dordrecht: Springer, pp. 51-64.

Botterill, L. C. (2006). Soap operas, cenotaphs and sacred cows: countrymindedness and rural policy debate in Australia. Public Policy, 1, 23-36.

Connell, D. (2007). Water Politics in the Murray Darling Basin. Sydney: Federation Press.

Courtice, B. (MP) (1989). Appropriation Bill (No 3) 1988-89. Debate House of Representatives, 11 April 1989. Canberra: Hansard.

Crase, L. (2011). The fallout to the guide to the proposed Basin Plan. Australian Journal of Public Administration, 70, 84-93.

Dovers, S. R. and Hezri, A. A. (2010). Institutions and policy processes: the means to the end of adaptation. Wiley Interdisciplinary Reviews: Climate Change, 1, 212-231.

Drought Pilot Review Panel (2011). Review of the Pilot of Drought Reform Measures in Western Australia: Issues Paper. Canberra: Commonwealth of Australia. Accessed 18 October 1012 from: < http://www.daff.gov.au/_data/assets/pdf_file/0011/1895852/ wa-sub-cover-sheet.pdf $>$.

Drought Policy Review Expert Social Panel (2008), It's About People: Changing Perspectives. A Report to Government by an Expert Social Panel on Dryness. Report to the Minister for Agriculture, Fisheries and Forestry. Canberra: Commonwealth of Australia. Accessed 18 June 2013 from: <http://www.daff gov.au/agriculture-food/ drought/drought-program-reform/national_review_of_drought_policy/social_assessment/
dryness-report $>$.

Drought Policy Review Task Force (1990). National Drought Policy Volume 1. Canberra: Australian Government Publishing Service.

Handmer, J. and Dovers, S. (2013). The Handbook of Disaster Policies and Institutions: improving emergency management and climate change adaptation. 2nd Edition, London: Earthscan.

Hennessy, K., Fawcett, R., Kirono, D. et al. (2008). An Assessment of the Impact of Climate Change on the Nature and Frequency of Exceptional Climatic Events. Canberra: Commonwealth of Australia. Accessed 18 October 1012 from: <http://www.daff.gov, au/data/assets/pdf_file/0007/721285/csiro-bom-report-future-droughts.pdf >

Hussey, K. and Dovers, S. (eds.) (2007). Managing Water for Australia: The Social and Institutional Challenges. Melbourne: CSIRO Publishing.

NWC - National Water Commission (2007). Australian Water Reform 2009: First Biennial Assessment of Progress in Implementation of the National Water Initiative. Canberra: Commonwealth of Australia.

NWC - National Water Commission (2009). Australian Water Reform 2009: Second Biennial Assessment of Progress in Implementation of the National Water Initiative. Canberra: Commonwealth of Australia.

Productivity Commission (2009). Government Drought Support: Productivity Commission Inquiry Report No 46, 27 February 2009. Canberra: Commonwealth of Australia. Accessed 18 June 2013 from: <http://www.pc.gov.au/projects/inquiry/drought/report>.

Ross, A. and Dovers, S. (2008). Making the harder yards: environmental policy integration in Australia. Australian Journal of Public Administration, 67, 245-260. Smith, D. I. (1998). Water in Australia: Resources and Management. Melbourne: Oxford
University Press. Troy, P. (cd.) (2008). Troubled Waters: Confronting the Water Crisis in Australia's Cities.
Canberra: ANU e-Press.

On Saturday, 7 destroyed by bus 2010). Fires bur more than one $h$ in Melbourne, is (Karoly, 2009; loss has raised $f$ safety in Victoric 'prepare, stay ar the preparednes: services and the risk areas. These Royal Commiss. report to the $\mathrm{Vi}$ the Commission conditions becau climate change a

This chapter Saturday' bushfi severity of the fir policy and mana The chapter conc in a changing cli

Bushfires are a weather conditio 


\title{
NATURAL DISASTERS AND ADAPTATION TO CLIMATE CHANGE
}

\author{
Edited by \\ SARAH BOULTER \\ National Climate Change Adoptation Research Facility, Oriffth University \\ JEAN PALUTIKOF \\ National Climare Change Adaptation Research Facility, Griffith University \\ DAVID JOHN KAROLY \\ University of Melboume \\ DANIELA GUITART \\ National Climate Change Adaptatlon Research Facillty, Griffith University
}




\section{CAMBRIDGE UNIVERSITY PRESS}

32 Avenue of the Americas, New York, NY 10013-2473, USA

Cambridge University Press is part of the Universily of Cambridge.

It furthers the University's mission by disseminating knowledge in the pursuit of education, learning, and research at the highest international levels of excellence.

Www.cambridge.org

Information on this kitle: www:cambridge.org/9781107010161

(C) Cambridge University Press 2013

This publication is in copyright. Subject to statutory axceptlon and to the provisions of relevant collective licensing agreements, In reproduction of any part may take place without the written permission of Cambridge University Press.

- $\quad$ First published 2013

Printed in the United States of America

A catalog record for this publication is available from the British Library.

Library of Congress Cataloging in Publication Data

Natural disasters and adaptation to climate change / [compiled by] Sarah Bou]ter, Griffith University, Jean Palatikof, Griffith University, David John Karoly, University of Melbourne, Dalicla Guitart, Griffth University.

2 pages cm

Includes bibliographical references and index.

ISBN 978-1-107-01016-1 (hardback)

1. Stonns. 2. Emergency management. 3. Disaster jelief. 4. fluman beings - Effect of climate on. I. Boulter, Sarah, 1970- editor of compilation. II. Palutikof, J. P. editor of compilation. III. Karoly, David John, 1955aditor of compilation. IV. Guitart; Daniela, 1988-aditor of compilation. HV635.5.N38 2014

363.34 de $23 \quad 2013019454$

ISBN 978-1-107-01016-1 Hardback

Cambridge University Press has no responsibility for the persistence or accuracy of URLs for external or third-party Intemet Web sites referred to in this publication and does not guarantee that any content on such Web sites is, or will remain, accurate or appropriate,
Contributor Preface

1 Introduction JEAN PALU DAVID JOHI

2 Climate cha challenges a MADELEINE

\section{Part I Case Stı}

A few words 0

3 Hurricane $\mathrm{K}$ ANDREW W

4 A brief histc Mississippi : TIMOTHY M

5 The 2003 an JON E. KEE: C. J. FOTHE

6 Adapting to Kansas City: DAVID M. M

Part II Case $\mathbf{S}$

7 Drought and to adaptatior LINDA C. BI 


\section{Contents}

$m y$

niversity, Jean Palutikof, affith University.

climate on. I. Boulter. y. David John, 1955on

Ir external or third-party such Web sites is, or will
Contributors

page ix

Preface

xiii

1 Introduction

JEAN PALUTIKOF, SARAH BOULTER, DANIELA GUITART, AND DAYID JOHN K.AROLY

2 Climate change and disaster risk management:

challenges and opportunities

MADELEINE C. THOMSON

\section{Part I Case Studies from North America}

A. few words on Andrew W. Garcia

3 Hutricane Katrina and the city of New Orleans 21 ANDREW W. GARCIA

$4 \mathrm{~A}$ brief history of flooding and flood control measures along the Mississippi River basin TTMOTHY M. KUSKY

5 The 2003 and 2007 wildfires in southern California JON E. KEELEY, ALEXANDRA D. SYPHARD, AND C. J, FOTHERINGHAM

6 Adapting to extreme heat events: thirty years of lessons learned from the Kansas City, Missouri, extreme heat program DAYID M. MILLS AND WILLIAM D. SNOOK

\section{Part II Case Studies from Australia}

7 Drought and water in the Murray-Darling basin: from disaster policy to adaptation 
8 After 'Black Saturday': adapting to bushfires in a changing climate JOSHUA WHITTAKER, JOHN HANDMER, AND DAVID JOHN KAROLY

9 Cyclone Tracy and the road to improving wind-resistant design MATTHEW MASON, KATHARINE HAYNES AND GEORGE WALKER

10 Adaptation and resilience in two flood-prone Queensland communities DAVID KING, ARMANDO APAN, DIANE KEOGH, AND MELANIE THOMAS

\section{Part III Case Studies from Europe}

11 Windstorms, the most costly natural hazard in Europe UWE ULBRICH, GREGOR C. LECKEBUSCH, AND MARKUS G. DONAT

12 The 2003 heatwave: impacts, public health adaptation and response in France

MATHILDE PASCAL, ALAIN LE TERTRE; AND KARINE LAAIDI

13 Lessons from river floods in central Europe, 1997-2010 ZBIGNIEW W, KUNDZEWICZ

14 Lessons learned from the North Sea flooding disaster in the Netherlands, 1953 PIRR VELLINGA AND JEROEN AERTS

21 Disasters an JESSICA AYI

22 What next? KAREN O'BI

23 Barriers and JON BARNE?

24 Lessons lear: SARAF BOU

25 Afterword: f during 2010DAVID JOHA Index

\section{Part IV Case Studies from the Developing World}

15 Adapting to drought in the West African Sahel SIMON P. J. BATTERBURY AND MICHAEL J. MORTIMORE

16 The 2004 Indian Ocean tsunami: Sri Lankan experience SAM S. L. HETTIARACHCHI AND W. PRIYAN S, DIAS

17 Recovery efforts: the case of the 2007 cyclone Sidr in Bangladesh BIMAL K. PAUL AND MUNSHI K. RAHMAN

18 Coffee, disasters and social-ecological resilience in Guatemala and Chiapas, Mexico

HALLIE EAKIN, HELDA MORALES, EDWIN CASTELLANOS, GUSTAVO CRUZ-BELLO, AND JUAN F, BARRERA

19 Responding to floods in the Nile basin: a case study of the 1997-1.998 floods in the Upper White Nile MARISA C. GOULDEN AND DECLAN CONWAY

20 Floods in the Yangtze River basin, China ZBIGNIEW W. KUNDZEWICZ, JIANG TONG, AND SU BUDA 
nate

.KER

sunities

95

IE

JONAT

onse

II

\section{Part V Synthesis Chapters}

21 Disasters and development JESSICA AYERS, SAI.EEMUL HUQ, AND SARAH BOULTER

22 What next? Climate change as a game-changer for policy and practice KAREN O'BRIEN AND THOMAS E. DOWNING

23 Barriers and limits to adaptation: cautionary notes JON BARNETT, COLETTE MORTREUX, AND W. NEIL ADGER

24 Lessuns learned for adaptation to climate change SARAH BOULTER, JEAN PALUTIKOF, AND DAVID JOHN KAROLY

25 Afterword: floods, storms, fire and pestilence - disaster risk in Australia during 2010-2011 DAVID JOHN KAROLY AND SARAH BOULTER Index 
